\title{
Pahami Aku (Lansia): Menumbuhkan Kesadaran Keluarga AkanPentingnya Dukungan Keluarga Pada Lansia
}

\author{
Santi Sulandari ${ }^{1}$, Mei Wijayanti ${ }^{2}$, Diyah Ayu Mastuti $^{3}$ \\ Fakultas Psikologi, Universitas Muhammadiyah Surakarta \\ e-mail: ${ }^{1}$ ss280@ums.ac.id, ${ }^{2}$ meiwijayanti285@gmail.com, ${ }^{3}$ diyahayumastuti@gmail.com
}

\begin{abstract}
Geriatric tend to face various problems at the end of his life. This can have an impact on the disparity and other psychological problems. Family support is one of the alternatives to minimize those problems. Nevertheless, based on previous research results in Luwang, Gatak, Sukoharjo shows that family support for in the village is low. Therefore, counseling on the importance of family support and how to treat the elderly well is necessary for this area. This counseling was given to older people families of 11 people. This volunteering used poster and self-note as the media to deliver the messages. Based on the counseling activities that have been done, the results obtained that 8 out of 10 elderly have increased score on posttest results conducted. Meanwhile, two other elderly people didn't have an increase or decrease in pretest and posttestscores.
\end{abstract}

Keyword:Family support, geriatric, geriatric's problem

Abstrak. Lansia (lanjut usia) cenderung menghadapi berbagai permasalahan di masa akhir kehidupannya. Hal ini dapat berdampak pada ketidakbahagian dan masalah-masalah psikologis lainnya. Dukungan keluarga merupakan salah satu alternatif untuk meminimalisir permasalahan pada lansia. Meskipun demikian berdasarkan hasil penelitian sebelumnya di Desa Luwang, Gatak, Sukoharjo menunjukkan bahwa dukungan keluarga pada lansia di desa tersebut tergolong rendah. Oleh karena itu, penyuluhan terkait pentingnya dukungan keluarga dan bagaimana cara memperlakukan lansia dengan baik sangat diperlukan di daerah ini. Penyuluhan ini diberikan kepada keluarga lansia sejumlah 11 orang. Media yang digunakan dalam penyuluhan ini adalah poster dan catatan diri. Berdasarkan kegiatan penyuluhan yang telah dilakukan, diperoleh hasil bahwa 8 dari 10 lansia mengalami peningkatan skor pada hasil posttest yang dilakukan. Sedangkan, 2 lansia lainnya tidak mengalami kenaikan maupun penurunan pada skor pretest dan post- test.

Kata kunci:Dukungan keluarga, lansia, permasalahan lansia 


\section{Pendahulan}

Masa usia lanjut merupakan masa yang tidak dapat dihindari oleh setiap manusia yang diberikan umur oleh Tuhan. Menjadi seorang lanjut usia (lansia) bukanlah suatu pilihan, namun merupakan suatu fase akhir kehidupan yang pasti akan dialami oleh sebagian besar individu. Fase tersebut merupakan proses perkembangan individu yang ditandai dengan berbagai perubahan fungsi fisik, psikis maupun sosial (Hurlock,1999).

Populasi lansia mengalami peningkatan dari tahun ke tahun. Berdasarkan hasil survey dari Badan Pusat Statistik [BPS] (2013), jumlah populasi lansia di Indonesia mengalami peningkatan di setiap tahunnya. Data pada tahun 2010 jumlah lansia sekitar 7,56\% dari jumlah penduduk Indonesia dan pada tahun 2015 meningkat menjadi $8,49 \%$. Populasi lansia diprediksi akan terus meningkat di tahun-tahun berikutnya. Berdasarkan survey tersebut telah diproyeksi populasi lansia pada tahun 2020sebesar9,99\%,padatahun2025meningkatmenjadi11,83\%danterusmeningkathingg a $13,82 \%$ pada tahun 2030 .

Populasi lansia yang terus meningkat diiringi munculnya berbagai permasalahan bagi lansia. Menurut Suardiman (2011) menyatakan bahwa terdapat empat permasalahan yang pada umumnya di alami saat usia lanjut, yaitu masalah ekonomi, masalah sosial budaya, masalah kesehatan, dan masalah psikologis. Lansia memiliki kapasitas yang kurang baik untuk beraktifitas secara optimal karena mereka cenderung depresi dalam menghadapi berbagai Permasalahan di masa akhir kehidupannya (Laksmana, 2013; Suardiman, 2011). Candra (2012) menyebutkan bahwa persentase lansia yang mengalami depresi berkisar antara 1-5\% dari populasi lansia. Angka ini akan mengalami peningkatan hingga 13,5\% pada lansia yang mengalami gangguanmedis.

Berdasarkan permasalahan-permasalahan yang muncul di usia lanjut maka dibutuhkannya dukungan dari lingkungan sekitar lansia khususnya keluarga. Menurut Komalasari (2006) kehadiran orang lain begitu diperlukan di dalam kehidupan seseorang. Oleh karena itu, individu khususnya lansia membutuhkan dukungan dari orang terdekat.

Terdapat banyak bentuk duk\ungan yang dapat dilakukan oleh keluarga 36 | Pahami Aku (Lansia)... 
lansia. Banyak ahli mengemukakan pendapat mengenai bentuk-bentuk dukungan keluarga kepada lansia, antara lain: House (dalam Glenz, 2008); Damayanti (2012); dan Turnbull, Summers, dan Trunbull (2007). House (dalam Glenz, 2008) mengidentifikasi bahwa terdapat empat tipe dukungan sosial: (1). Dukungan Emosional (emotional support) yaitu dukungan yang dibutuhkan oleh individu yang berupa empati, cinta, dan kepercayaan diri sebagai bentuk yang menghasilkan motivasi, perhatian dan perasaan untuk didengarkan oranglain, sedangkan empati terwujud dalam sikap ikut merasakan emosi yang dialami individu lain; (2) Dukungan instrumental (instrumental support), yaitu adanya bantuan nyata (fisik) dalam menunjang layanan, misalnya: bantuan peralatan, uang, transportasi, waktu dan lingkungan yang menyangkut kebutuhan hidup; (3) Dukungan Informasi (informational support), yaitu mendapatkan pemberian nasehat, pemberian saran, dan penyediaan informasi umum yang dibutuhkan seseorang; (4) Dukungan Penilaian (appraisal support), yaitu pemberian informasi yang dapat berguna untuk penilaian diri, berupa penilaian yang dirasakan positif dapat membantu individu dalam meningkatkan identitas pribadi serta pengembangan kepribadian.

Menurut Damayanti (2012) menyatakan bahwa dukungan keluarga lebih mengacu pada kepada pemberian semangat, kehangatan dalam keluarga, cinta yang terwujud dalam keluarga, kasih sayang yang diberikan dan emosi. Turnbull, Summers, dan Trunbull (2007) menambahkan bahwa lansia juga membutuhkan dukungan dan layanan seperti: adanya perawatan tangguh, seperti penyediaan informasi (berupa sumber daya masyarakat, tunjangan dari pemerintah, hak-hak hukum, dan informasi mengenai kecacatan). Dungan emosional diantara seperti: pelayanan konseling, partisipasi yang terdapat dalam dukungan kelompok.

Suardiman (2011) menyatakan bahwa secara psikologis, lansia akan merasa bahagia apabila mendapatkan dukungan sosial yang membuat lansia merasa nyaman, tentram, dan damai dalam menjalani kehidupannya. Adanya dukungan membuat lansia memiliki harapan hidup untuk tetap aktif (active life expectancy). Dukungan sosial keluarga juga dapat meningkatkan kesehatan dan kesejahteraan pada lanjut usia (Dharma, 2014; Ikasi dkk, 2014). Kristyaningsih (2011) menambahkan bahwalansiayang memiliki dukungan keluarga yang tinggi dapat menurunkan 
tingkat depresi pada lansia tersebut.

Selain itu, dukungan keluarga sangat penting bagi lansia untuk mendampinginya dalam penyesuaian diri lansia terhadap perubahan-perubahan yang terjadi dalam hidupnya. Hal ini menunjukkan, adanya dukungan keluarga dapat meningkatkan kualitas hidup lansia secara optimal atau bisa diartikan sebagai kondisi fungsional lansia yang berada pada kondisi maksimum atau optimal, sehingga lansia dapat menikmati masa tuanya dengan penuh makna, membahagiakan, berguna dan berkualitas (Sutikno,2011).

Berdasarkan penelitian yang telah dilakukan oleh Mastuti pada tahun 2016 di kelurahan Luwang, Kecamatan Gatak, Kabupaten Sukoharjo, diperoleh hasil bahwa dukungan keluarga terhadap lansia di daerah tersebut tergolong rendah terhadap lansia. Berdasarkan hasil observasi Mastuti banyak lansia yang merasa kesepian meskipun tinggal bersama keluarga, terdapat lansia yang merasa diasingan di dalam keluarga sendiri sehingga mencari kesibukan diluar rumah seperti bertani, berdagang di pasar, maupun aktif dalam kegiatan sosial. Selain itu, terdapat kemungkinan bahwa kurangnya informasi bagi keluarga mengenai kebutuhan individu di usia lanjut.

Subjek penelitian Mastuti (2016) adalah lansia yang tinggal dengan keluarga, namun pada kenyataannya hasil penelitian menunjukkan bahwa dukungan keluarga rendah. Hal ini tentunya menjadi tanda tanya besar ketika seorang lansia tinggal dengan keluarga namun merasakan dukungan yang kurang dari keluarganya. Hal ini dimungkinkan karena keluarga tidak memahami pentingnya dukungan keluarga atau cara memperlakukan lansia dengan baik. Oleh karena itu diperlukan penyuluhan di desa tersebut untuk menumbuhkan kesadaran keluarga akan pentingnya dukungan keluarga pada lansia agar dapat meningkatkan kejehteraan psikologis pada lansia.

\section{Metode}

Tahap pelaksanaan pengabdian masyarakat yang dilakukan oleh penulis adalah sebagai berikut: Kegiatan pengabdian masyarakat ini dilaksanakan di kelurahan Luwangan, Kecamatan Gatak, Kabupaten Sukoharjo dalam dua kali tahap pelaksanaan, yaitu tahap pre- test dan tahap posttest. Pelaksanaan pretest dilakukan dalam tigakalikunjungan yaitu pada tangggal 9, 23, dan 30 Desember 2017. Pada tahap pretest peneliti memberikan skala dukungan keluarga kepada lansia yang tinggal 38 | Pahami Aku (Lansia)... 
bersama keluarga. Selain itu, peneliti memberikan penyuluhan kepada keluarga dimana lansia tersebut tinggal mengenai beberapa cara yang dapat dilakukan keluarga untuk memahami lansia. Setelah penyuluhan dan pemberian skala telah dilakukan, peneliti memberikan jurnal harian kepada peserta penyuluhan (anggota keluarga berusia $\geq 17$ tahun) untuk diisi selama 30 hari setelah hari penyuluhan. Jurnal harian tersebut berisi tentang cara keluarga memberikan dukungan kepada lansia sesuai dengan isi penyuluhan yang telah diberikan.

Selanjutnya, tahap posttestdilakukan dengan memberikan skala posttestdukungan keluarga kepada lansia yang telah diberikan skala pretest sebelumnya. Setelah itu, penulis mengumpulkan jurnal harian yang telah diberikan sebelumnya kepada peserta penyuluhan pada tahap pretest.

Jenis metode pengabdian yang di berikan berupa penyuluhan terhadap anggota keluarga lansia dengan menggunakan media cetak (poster) yang berisikan tentang permasalahan - permasalahan yang di hadapi saat di usia lanjut serta peran keluarga di dalamnya.Terdapat 2 macam teknik pengumpulan data yang digunakan pada kegiatan pengabdian yang dilakukan, yaitu Jurnal Harian dan Skala Dukungan Keluarga. Jurnal Harian diberikan kepada anggota lansia setelah penyuluhan. Jurnal tersebut terdapat 8 item yang berisikan bentuk dukungan keluarga terhadap lansia saat di rumah, keluarga diminta untuk mengisi jurnal tersebut selama 30 hari setelah penyuluhan. Tugas anggota keluarga hanya mencentang aitem tersebut setiap hari jika mereka melalukan hal tersebut pada hari tersebut. Skala dukungan keluarga diberikan kepada lansia sebelum (pretest) dan sesudah (posttest) penyuluhan. Posttest diberikan setelah 1 bulan dari dilaksanakannyapenyuluhan.

\section{Hasil dan Pembahasan}

Berdasarkan penyuluhan kepada anggota keluarga lansia yang telah dilakukan tersebut, diperoleh hasil dari seluruh peserta penyuluhan beserta beberapa anggotakeluarga tambahan (6 orang) yang bersedia untuk mengisi jurnal harian meskipun tidak mengikuti penyuluhan. Diperoleh hasil sebagai berikut :

Tabel 1.Hasil Perhitungan Jurnal Harian oleh Anggota Keluarga Lansia 


\begin{tabular}{lllllllll}
\hline No. item Jurnal Harian & 1 & 2 & 3 & 4 & 5 & 6 & 7 & 8 \\
\hline Skor Tota* (17 Informan) & 418 & 279 & 177 & 313 & 435 & 68 & 370 & 346
\end{tabular}

*) skor total diperoleh dari nxa; $\mathrm{n}=$ jumlah informan dan $\mathrm{a}=$ jumlah jurnal harian yang diisi anggota keluarga per hari (max skor per informan 30)

Keterangan item:

1 : Saya memperhatikan lansia dan memenuhi kebutuhannya.

2 : Saya menemani lansia melakukan aktivitas hariini.

3 : Saya menanyakan kabar lansia hariini.

4 : Saya memenuhi keinginan lansia hariini.

$5 \quad$ : Hari ini saya menemani lansia untukmengobrol.

6 : Saya mengajak lansia bepergian/ keluar rumah hariini.

7 : Saya bersabar/tidak marah dengan keinginanlansia

8 : Saya mengajak/ mendukung dan memberikan kesempatan lansia untuk melakukan kegiatan di luarrumah.

Sesuai dengan hasil jurnal harian diatas, diperoleh hasil bahwa informan (keluarga lansia) lebih sering melakukan/menemani lansia untuk mengobrol meskipun sekedar untuk mengobrol hal yang ringan. Sedangkan, total skor yang paling sedikit dilakukan oleh infoman adalah mengajak lansia bepergian/keluar rumah. Hal ini dimungkinkan karena kondisi lansia yang kurang fit untuk beraktifitas lebih diluar rumah.

Selain itu, berdasarkan hasil pretest dan posttest yang dilakukan kepada 10 lansia, diperoleh hasil sebagai berikut: 
Tabel. 2 hasil pretest dan posttest

\begin{tabular}{ccccc}
\hline No & Nama Lansia & JK & Skor Pretest & Skor Posttest \\
\hline 1. & SU & P & 91 & 96 \\
\hline 2. & PA & P & 74 & 74 \\
\hline 3. & SA & P & 112 & 114 \\
\hline 4. & JG & P & 101 & 105 \\
\hline 5. & JU & P & 76 & 76 \\
\hline 6. & RE & P & 81 & 84 \\
\hline 7. & RO & P & 110 & 113 \\
\hline 8. & TO & L & 92 & 96 \\
\hline 9. & PO & P & 103 & 111 \\
\hline 10. & TM & L & 93 & 98 \\
\hline
\end{tabular}

Berdasarkan data diatas dapat diperoleh hasil bahwa pelaksanaan penyuluhan terhadap keluarga lansia dapat dikatakan berhasil, dapat dilihat dari hasil posttest dimana sebagian besar yaitu 8 responden mengalami kenaikan dari hasil pretest yang diberikan. Selain itu, terdapat 2 lansia yang tidak mengalami kenaikan maupun penurunan skor setelah dilaksanakannya penyuluhan tersebut. Hal ini dimungkinkan karena kesibukan dari anggota keluarga, sehingga kurang adanya perhatian lebih yang diberikan kepada lansia.

Memasuki periode lansia merupakan masa dimana dibutuhkannya pendampingan yang lebih dibandingkan periode sebelumnya karena mulai muncul adanya rasa takut akan kematian, kesepian, penyakit, dan kematian. Penyebab paling umum dari bunuh diri pada orang tua, dapat disebabkan karena melemahnya koneksi dengan lingkungan sekitar dalam arti semakin lansia merasa terisolasi, kesepian dan juga frustasi. Perasaan tersebut muncul saat masa pasangan hidup meninggal, atau di tinggal anaknya karena sudah menikah dan hidup jauh dari orang tua. Perasaan kesepian mental dan sosial, juga sebagai rasa keterasingan, seringkali dibenarkan bukan secara umum/objektif tetapi subyektif pada situasi setiap lansia. Selain itu,adanyakebutuhan yang semakin kuat dibandingkan tahun-tahun sebelumnya 
akan keamanan, rasa hormat, dan rasa memiliki. Oleh karena itu, lingkungan terbaik yang memungkinkan untuk memenuhi semua kebutuhan tersebut adalah keluarga (Świderska,2014).

Keluarga merupakan suatu hal yang penting bagi lansia. Saat ini, ketika usia harapan hidup diperpanjang dan orang-orang yang pensiun memiliki kemampuan penuh atas pikiran dan kekuatan fisik mereka, maka mereka memiliki kebutuhan yang besar, yaitu ingin mempertahankan kontak dengan lingkungan, stereotip usia tua dikaitkan dengan penyakit, ketergantungan pada orang lain, tidak memiliki kesempatan, dan kehilangan aktualitas (Świderska, 2014).

Kegiatan pengabdian masyarakat ini menggunakan jurnal harian yang berisikan bentuk-bentuk dukungan keluarga kepada lansia. Hasil yang diperoleh dari jurnal harian yang tersebut menunjukkan bahwa bentuk dukungan kepada lansia yang di berikan oleh keluarga adalah mayoritas menemani lansia untuk mengobrol. Hal tersebut sejalan dengan pendapat dari Mestheneos \& Triantafillou dalam EUROFAMCARE yang menyatakan pendapat bahwa dukungan keluarga (Family Care) merupakan hal yang diberikan oleh anggota keluarga untuk seseorang di usia 65 tahun atau lebih yang membutuhkan setidaknya 4 jam perawatan pribadi atau dukungan per minggunya, baik itu di rumah atau di lembaga perawatan.

Menurut Świderska (2014) menyatakan bahwa bagi orang tua/lansia, kebutuhan tidak selalu berkaitan dengan masalah keuangan, tetapi juga emosional yang berarti, seperti ekspresi ingatan, keintiman/kedekatan, rasa hormat, dan keramahan serta saling mendukung dan menolong satu sama lain. Berkaitan dengan skala dukungan keluarga yang telah diberikan kepada lansia, dimana hasil posttest (setelah penyuluhan terhadap anggota keluarga) menunjukkan peningkatan skor dibandingkan hasil pretest. Hal ini menunjukkan bahwa terdapat perubahan yang dirasakan oleh lansia terkait dengan dukungan dari keluarga lansia itu sendiri. Selain itu, dapat dikatakan bahwa kualitas dukungan yang diberikan lebih baik dari pada sebelumnya.

\section{Simpulan}

Berdasarkan kegiatan pengabdian masyarakat yang telah dilakukan dapat disimpulkan bahwa lansia memerlukan dukungan dari keluarga terdekat dan 42 | Pahami Aku (Lansia)... 
lingkungan sekitar dalam menghadapi perubahan-perubahan yang terjadi di usia lanjut. Selain itu, keluarga dapat memberikan berbagai dukungan terhadap lansia dengan berbagai cara misal: perhatian, menemani, memahami, dsb. Dengan adanya penyuluhan ini maka keluarga dari lansia menjadi mengetahui bahwa kebutuhan lansia selama ini adalah dukungan dan perhatian dari keluarga dan lingkungan. Kesadaran dari lingkungannya lansia atas pemberian kasih sayang kepada lansia merupakan hal yang utama sehingga lansia dapat menjalankan sisa hidupnya dengan lebih tenang danbermakna.

\section{Daftar Pustaka}

Badan Pusat Statistik [BPS]. (2013). Proyeksi Penduduk Indonesia 2010-2035. Jakarta : Badan Pusat Statistik.

Chandra, V. (2012). Desain Panti Sosial Tresna Wredha Abiyoso Sleman, Yogyakarta (Skripsi tidak dipublikasikan). Program Studi Arsitektur Fakultas Teknik Universitas Atma Jaya Yogyakarta, Yogyakarta. Diunduh dari http://ejournal.uajy.ac.id/1070/3/2TA12520.pdf.

Damayanti, E. (2012). Dukungan Keluarga Terhadap Lansia. Diunduh dari http://erindamayanti.wordpress.com.

Dharma, A. (2014). Bentuk Dukungan Keluarga Pada Lansia Etnis Tionghoa Di Kota Bandung. pp. A_19-A_26.

Glenz, K. (2008). Health Behavior And Health Education. In H. E. Behavior, Community And Group Models Of Health Behavior Of Change (pp. 284- 517). America: Jossey- Bass.

Hurlock, E. B. (1999). Psikologi Perkembangan Suatu Pendekatan Sepanjang Rentang Kehidupan. Jakarta: Erlangga.

Ikasi, A., Jumaini, \& Hasanah, O. (2014). Hubungan Dukungan Keluarga Terhadap Kesepian (Lonelinnes) Pada Lansia. JOM PSIK, 1 (2), 1-7.

Komalasari, E. (2006). Dukungan Sosial Pada Penderita Penyakit Jantung Di Rumah

Sakit Harapan Kita.(Skripsi). Jakarta: Fakultas Psikologi Universitas Gunadarma

Kristyaningsih, D. (2011). Hubungan antara dukungan keluarga dengan tingkat depresi pada lansia. Jurnal Keperawatan, 1(1),1-8

Laksmana, G. (2013) Oktober 8). Tetap Sehat di Usia Lanjut. Suara Merdeka.

Diunduh 